\title{
Characterization and Classification of Different Rice Growing Soils with Special Emphasis on Soil Organic Carbon Stock in Rajnagar Block of Birbhum District, West Bengal
}

\author{
Shreyasi Gupta Choudhury ${ }^{1 *}$, Tapati Banerjee ${ }^{1}$, Krishnendu Das ${ }^{1}$, \\ A.K. Sahoo ${ }^{1}$, D.C. Nayak ${ }^{1}$ and S.K. Singh ${ }^{2}$ \\ ${ }^{I}$ ICAR-National Bureau of Soil Survey and Land Use Planning, Regional Centre, \\ Kolkata-700091, West Bengal, India. \\ ${ }^{2}$ ICAR-National Bureau of Soil Survey and Land Use Planning, Amravati Road, \\ Nagpur-440033, Maharashtra, India
}

\begin{abstract}
Characterization and classification of rice growing soils of rainfed region of West Bengal is having an utmost importance for developing optimal agricultural land use planning. In the context of ever increasing food demand under dwindling agricultural land availability, rainfed areas have got the attention for enhancing food grain production for the national food basket. Hence, in the present study, we made an effort to characterize six rice growing soils placed in six different landform situations (plateau top, dissected plateau, plateau fringe, undulating upland, alluvial plains and valley fill) and classify accordingly for resource inventory of Rajnagar block, Birbhum district, West Bengal. Results depicted that, rice is grown mainly in Alfisols and Inceptisols in this block with varying morphological and physico-chemical characteristics. The soils are moderately deep to very deep with sandy loam to clay loam surface texture. Soils of plateau top, dissected plateau, plateau fringe, undulating upland, alluvial plains and valley fill were classified as Typic Haplustalfs, Aeric Endoaqualfs, Typic Haplustalfs, Typic Haplustepts, Aeric Epiaquepts, Oxyaquic Haplustalfs, respectively. The double crop rice ecology (rice-mustard) showed significantly $(\mathrm{P}=0.05)$ higher surface soil organic carbon $(\mathrm{SOC})$ stock as compared to the other monocrop rice ecologies. Among all the landforms compared, soils of valley fill region had the highest surface SOC stock (14.5 Mg $\left.\mathrm{ha}^{-1}\right)$ followed by plains $\left(10.4 \mathrm{Mg} \mathrm{ha}^{-1}\right)$, plateau fringe $\left(7.7 \mathrm{Mg} \mathrm{ha}^{-1}\right)$, plateau top $\left(8.1 \mathrm{Mg} \mathrm{ha}^{-1}\right)$, dissected plateau (7.2 $\left.\mathrm{Mg} \mathrm{ha}^{-1}\right)$ and upland $\left(6.9 \mathrm{Mg} \mathrm{ha}^{-1}\right)$. Significantly $(\mathrm{P}=0.05)$ higher total profile SOC stock suggested a better soil health in valley fill and plains as compared to other areas that enhances our understanding about the need of the implementation of carbon management based land use planning for higher future productivity of these soils under environmental sustenance.
\end{abstract}

Keywords: Soil characterization and classification, rice soils, rainfed zone

\section{Introduction}

Systematic inventory and characterization of soil resources is the basic need for developing a sustainable agricultural land use plan at block level. The growing demand of food and non-food commodities is supposed to increase by $75-100 \%$ globally between 2010-2050 (Keating et al., 2010; Tilman et al., 2011., Hosain et al., 2016). It is estimated that rice production has to be increased by $1.1 \%$ per annum, for ensuring South Asian food security in next four decades (Ladha et al., 2003; Gathala et al., 2013). Simultaneously, in our country, there is a severe decline in land availability for irrigated agriculture. Thus, the situation

*Corresponding Author Email: shreyasi.acss@gmail.com of shrinking agricultural land availability and the swelling requirement for food, demands our attention towards utilizing the soils of rainfed areas, where there is potential to increase the crop productivity. Rice soils of rainfed region are to be characterized and classified for assessment and optimum future land suitability and land use planning. Moreover, for mitigating the danger of global warming and improving soil health security in this region in the light of climate change, estimation of soil organic (SOC) stocks in rice soils is important. Hence, an attempt has been made to characterize and describe the rice growing soils of Rajnagar block belonging to the rainfed zone of West Bengal with an attention to its soil organic carbon stock for future carbon and crop modeling. 


\section{Materials and Methods}

Rajnagar block in Birbhum district of West Bengal is situated in the eastern extension of Chhotanagpur plateau characterized by undulating and dissected terrain interspersed by hillocks and valleys. The area extends between $23^{\circ} 52^{\prime} 12.1^{\prime \prime} \mathrm{N}$ to $24^{\circ} 02^{\prime} 43.8^{\prime \prime} \mathrm{N}$ latitude and $87^{\circ} 14^{\prime} 04.6^{\prime \prime}$ E longitude to $87^{\circ} 27^{\prime} 46.9^{\prime \prime}$ E covering about 22,147 ha of geographical area with 99 villages (Fig. 1).

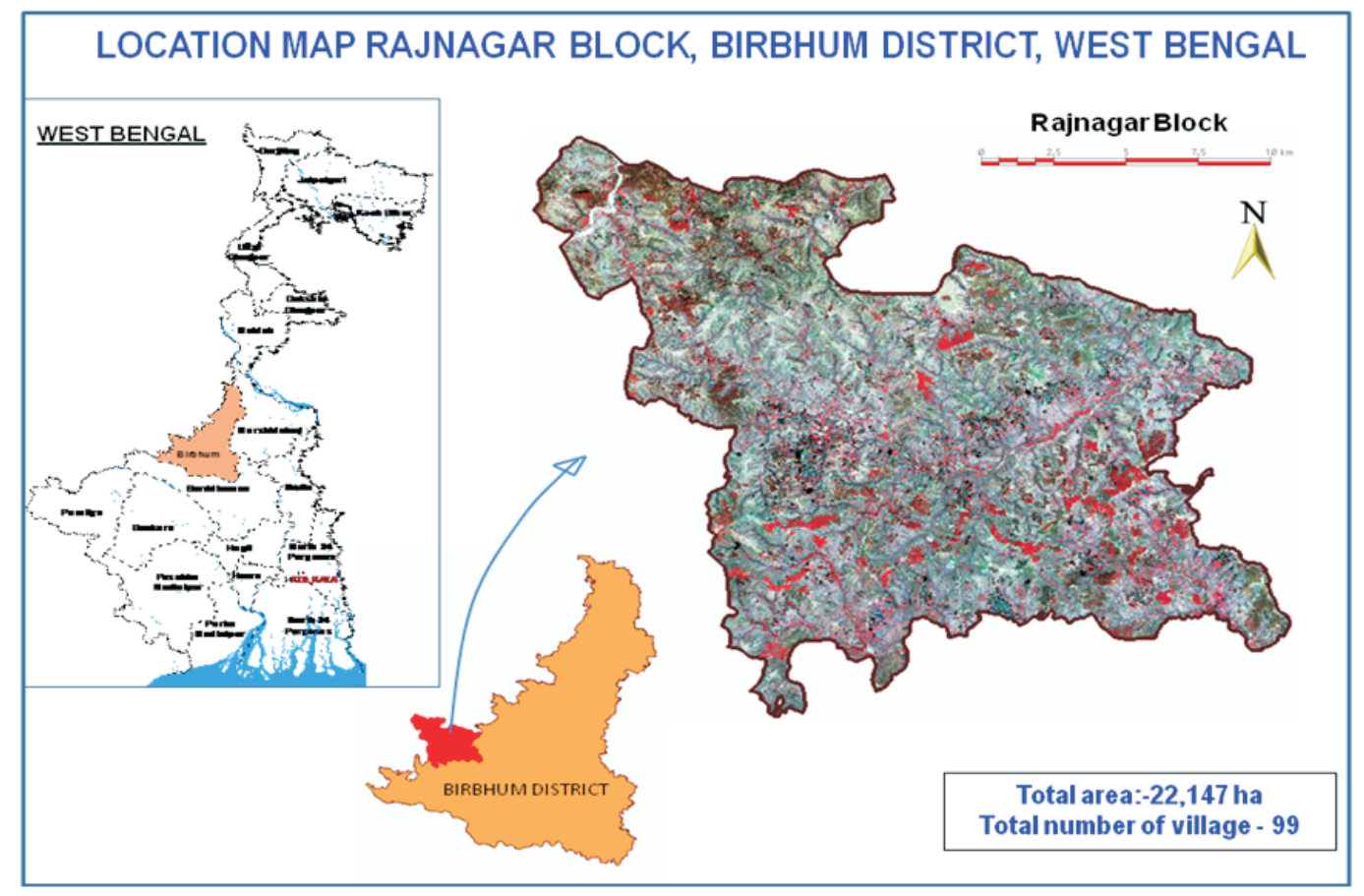

Fig 1. Location map of Birbhum District

The area represents the rainfed region of agroecological sub-region (AESR) 12.3 with hot, dry-sub-humid climate with an average annual rainfall of $1300 \mathrm{~mm}$. The mean temperature is $22^{\circ} \mathrm{C}$ with a mean summer temperature of $31^{\circ} \mathrm{C}$ and mean winter temperature of $19.7^{\circ} \mathrm{C}$ with soil temperature regime "hyperthermic" and soil moisture regime "ustic". The relative humidity ranges from 43-83 percent. High relative humidity ranges between 75 to 83 percent during June to September, maximum being in the month of August. The Length of Growing Period (LGP) for the block is 180-210 days (Velayutham et al., 1999). For detailed identification and characterization of existing rice growing soils in different landforms of Rajnagar block, land resource inventory has been done at 1: 10000 scale with the base map prepared using satellite data (IRS P6 LISS-IV), Digital Elevation Models (DEM) and Survey of India topographical map of 1: 50000 scale (Soil Survey Staff, 1993). To visualize the range of soil variability under rice cultivation along different landform units (Fig. 2), transect selection and sampling intervals were determined by following the method of Teka et al. (2015). Three replicates of a single representative soil were collected from each of the six landforms situations for the present study (Table 1). Profile soil samples were collected during November to December, 2015 from each horizon of the pit (upto $1.5 \mathrm{~m}$ or morrum layer), dried and ground in shade and passed through $2 \mathrm{~mm}$ sieve. The samples thus obtained were used to determine soil texture (International pipette method), $\mathrm{pH}$, electrical conductivity (EC), cation exchange capacity (CEC), $\mathrm{Ca}^{2+}, \mathrm{Mg}^{2+}, \mathrm{K}^{+}, \mathrm{Na}^{+}$(Jackson, 1973), organic carbon (Walkey and Black, 1934), available nitrogen (Kjeldahl method; Christensen and Fulmer, 1927), available phosphorus (Bray and Kurtz, 1945), available potassium (neutral normal ammonium acetate methods, Hanway and Heidel, 1952), available cationic micronutrients through DTPA extraction method and in-situ bulk density through core method. The SOC stock was determined by multiplying the SOC content with its corresponding bulk density and surface soil depth. After synthesizing the laboratory data with the field data, final soil classification was made for the rice growing soils occupying $\sim 14000$ ha of land (District Statistical Handbook, 2012). 


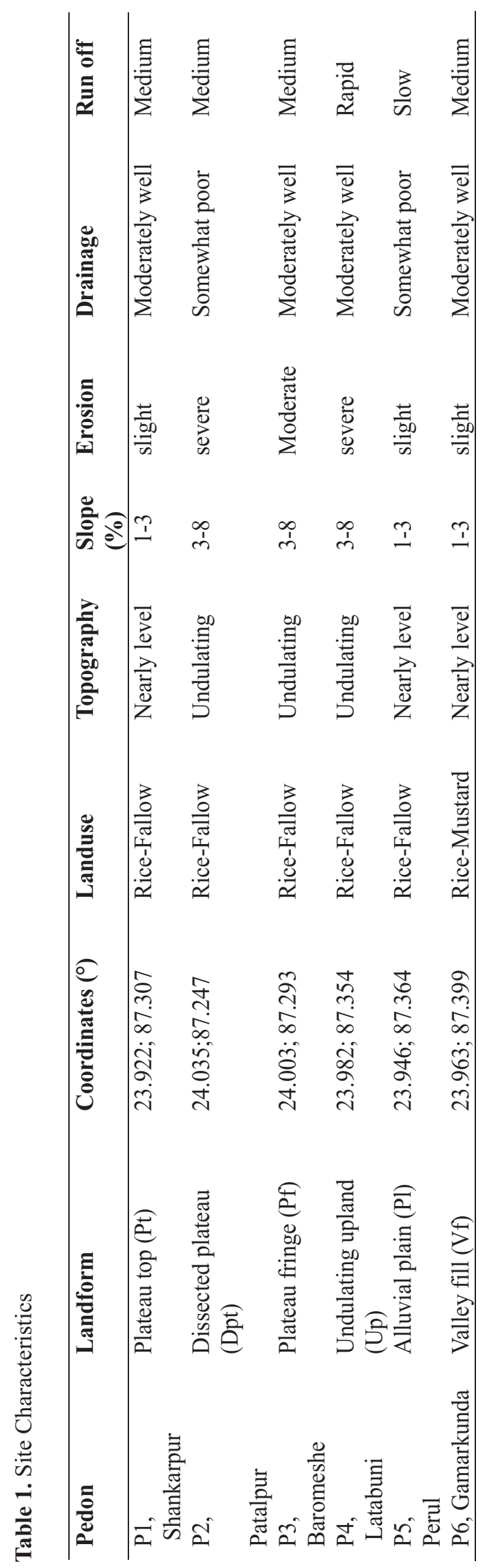




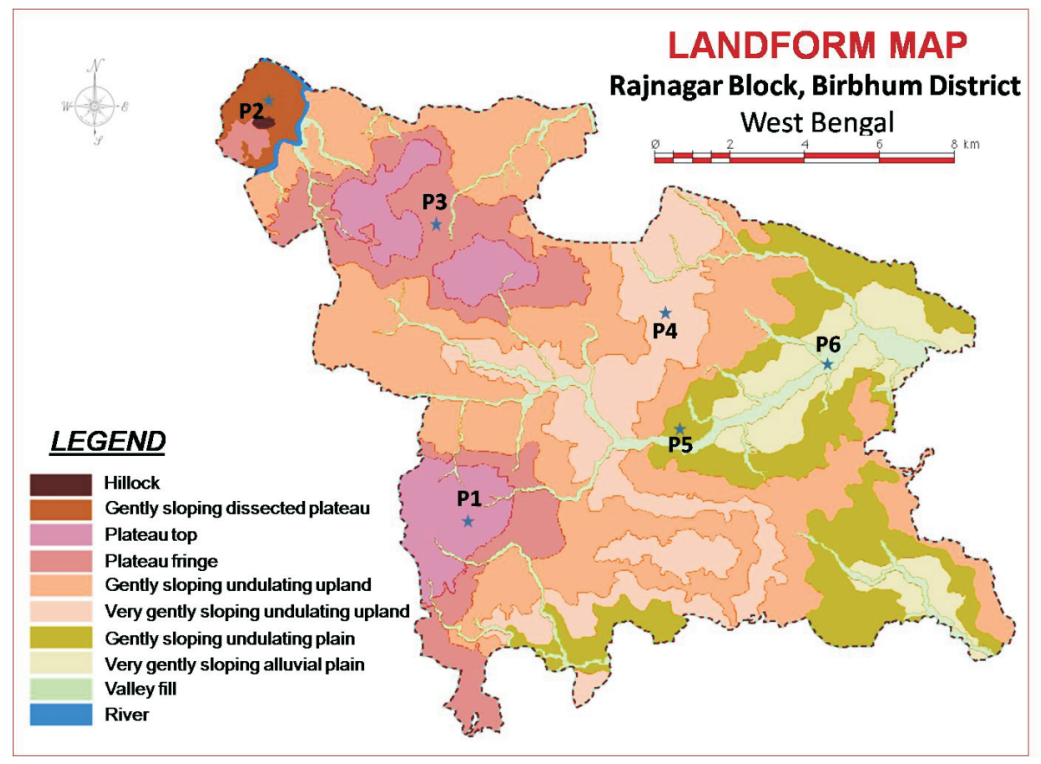

Fig. 2. Landform map of Rajnagar block, Birbhum district, West Bengal

\section{Results and Discussion \\ Soil morphological characterization}

The six rice growing soils situated in different landform showed different morphological characters. The detail of the soil morphological properties is presented in Table 2. In Rajnagar block, rice is grown mainly in Alfisols and Inceptisols. Soils are moderately deep to deep with varying texture ranging from sandy loam to clay loam. Gangopadhyay et al. (2015) reported the presence of coarse textured surface soils with bright colour in undulating upland of Subarnarekha catchment of extended Chhotanagpur plateau. The different horizons have mostly clear smooth to gradual smooth boundary depending on the location. The matrix is mainly bright in colour with $10 \mathrm{YR}$ Hue in the surface, and $2.5 \mathrm{Y}$ in the sub-surface soils with Value and Chroma ranging from 3 to 5 and 2 to 6 , respectively, in plateau top, dissected plateau and plateau fringe except in the valley fill region, where, the lower horizons hold the similar Hue as the surface soil. The upland and plain soils are having 2.5Y Hue throughout the profile with Value and Chroma ranging from 4 to 5 and 2 to 6 , respectively. The lower horizons had mottles of redder colour, which might be a result of alternate oxidation and reduction process in subsurface soils. The presence of soils under Chroma 2 in the lower horizon of soils of dissected plateau and plains showed gleying, which indicated the presence of water in the lower horizon for a certain period of time (Bhattacharyya et al., 2009). Fine to coarse roots were found in the top three layers of the soil profiles in all the landforms. The soils are mostly sub angular blocky to sometimes granular in structure. The soils are having loose to slightly hard, friable to firm and slightly sticky-slightly plastic to very sticky-very plastic soil consistencies in dry, moist and wet situations, respectively.

\section{Soil physico - chemical characterization}

The studied soils of different landforms are physico-chemically characterized and presented in Table 3. In general, the surface soils are acidic to neutral in nature with $\mathrm{pH}$ ranging from 5.1 to 6.7 . The sub-surface soils are slightly acidic to slightly alkaline in nature. The low EC $(0.03$ to $0.3 \mathrm{dSm}^{-1}$ ) indicated low concentration in soil solution. Irrespective of all the landforms, SOC content was low to medium $(0.2$ to $0.55 \%)$. The organic carbon content of all the soils decreased with increasing depth. The relatively higher SOC in the surface soil might be due to the mat forming root structure of rice plants, which would add a considerable portion of the total rice biomass (Mandal et al., 2008). The cultivation of double crop in the valley fill region resulted in deposition of more plant residues in terms of root and shoot biomass, which might increase the SOC content in that region as compared to other monocropped rice ecology (Gupta Choudhury et al., 2014). The CEC and base saturation ranged from 4.5 to $19.4 \mathrm{cmol}\left(\mathrm{p}^{+}\right) \mathrm{kg}^{-1}$ and from 62 to $96 \%$, respectively. Out of the total exchangeable bases, calcium shared the maximum proportion (52 to $73 \%$ of the total exchangeable bases) followed by magnesium (21 to $30 \%$ ), sodium (1-22\%) and potassium (1.1 to $3.6 \%$ ). 


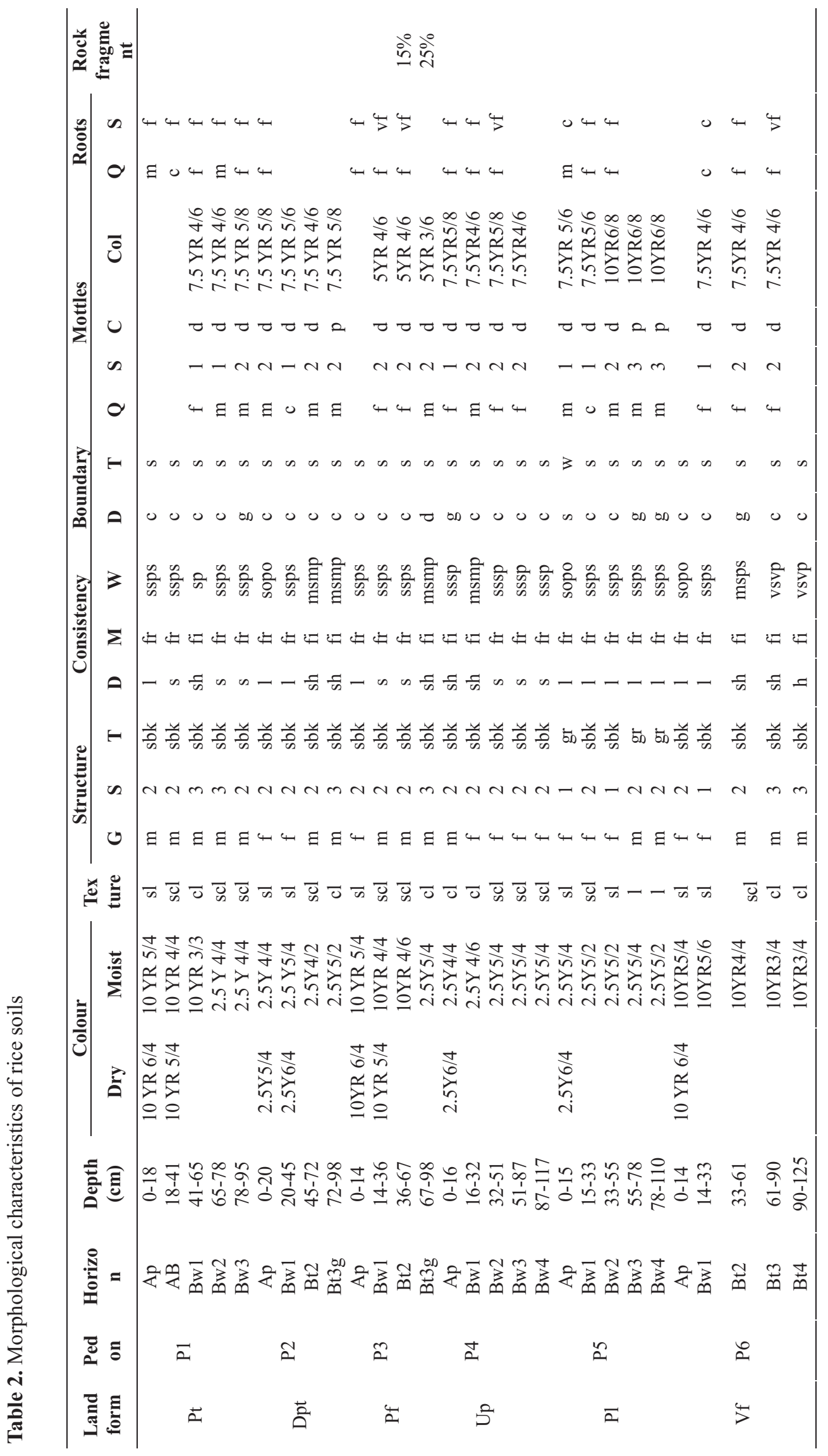




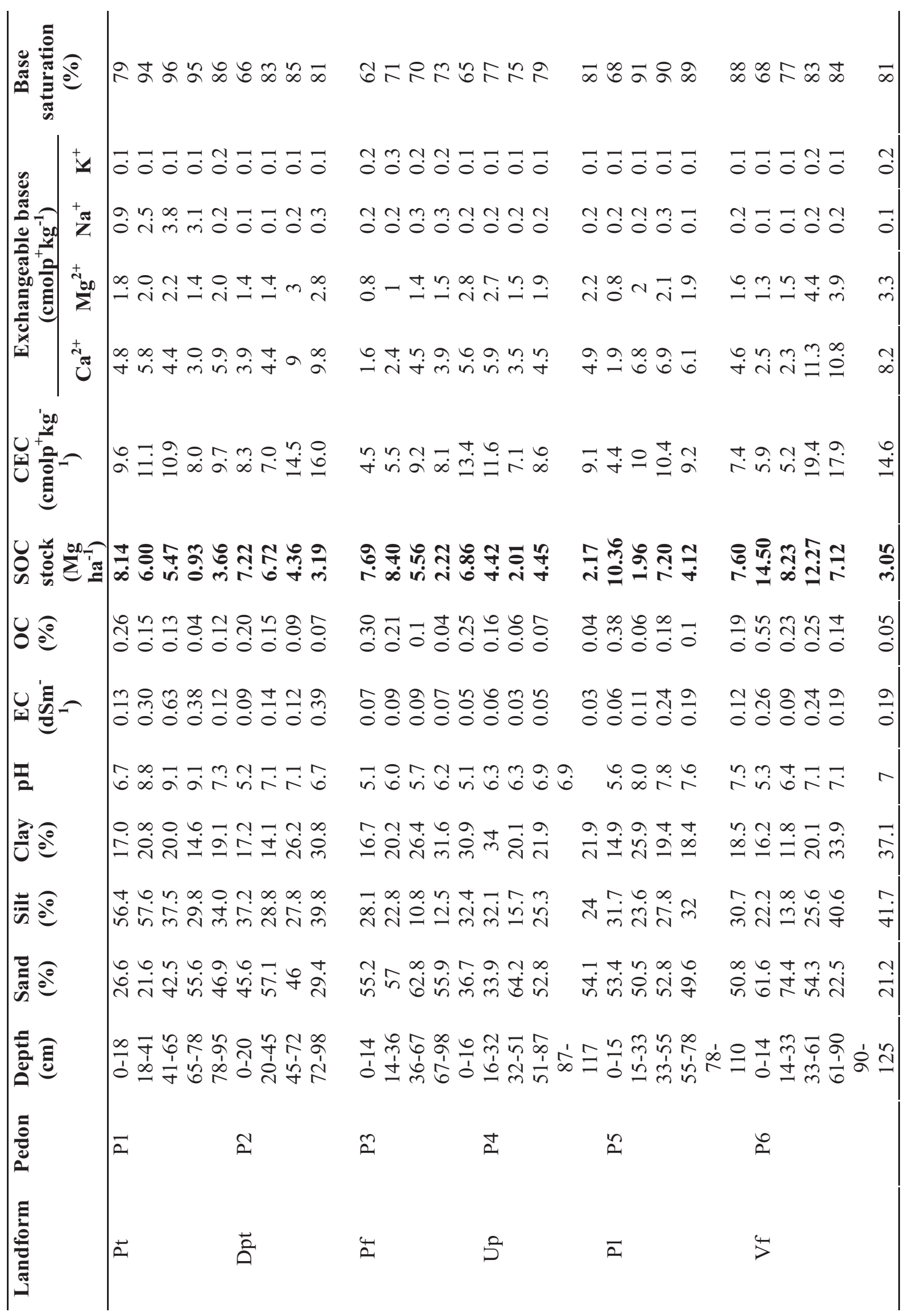




\section{Distribution of available macro and micro nutrients}

The macro and micro nutrient availability in different rice growing soils showed that the nitrogen and potassium availability were maximum in plateau fringe region, whereas the maximum phosphorus availability was observed in valley fill area (Fig. 3). Rice is grown in depositional phase of plateau fringe area, which accumulates the wash out materials from plateau and hillock. The higher $\mathrm{N}$ and $\mathrm{K}_{2} \mathrm{O}$ concentration in plateau fringe rice soil area might be due to the deposition and accumulation of washed out nutrients from plateau and hillock. The higher $\mathrm{P}_{2} \mathrm{O}_{5}$ availability in the valley fill region might be a result of neutral soil $\mathrm{pH}$, in which it would get less chance to be fixed in soil by $\mathrm{Ca}, \mathrm{Mg}, \mathrm{Fe}$ and $\mathrm{Al}$ ions. The micro nutrient availability ranged from 0.7 to $1.7 \mathrm{ppm}$ for $\mathrm{Cu}$, from 0.3 to $1.1 \mathrm{ppm}$ for $\mathrm{Zn}$, from 14.2 to 52.2 ppm for Fe and from 15.7 to $51.0 \mathrm{ppm}$ for Mn (Fig. 3). The values showed similarity with the results reported by (Gangopadhyay et al., 2012) while working in soils of rainfed zone.

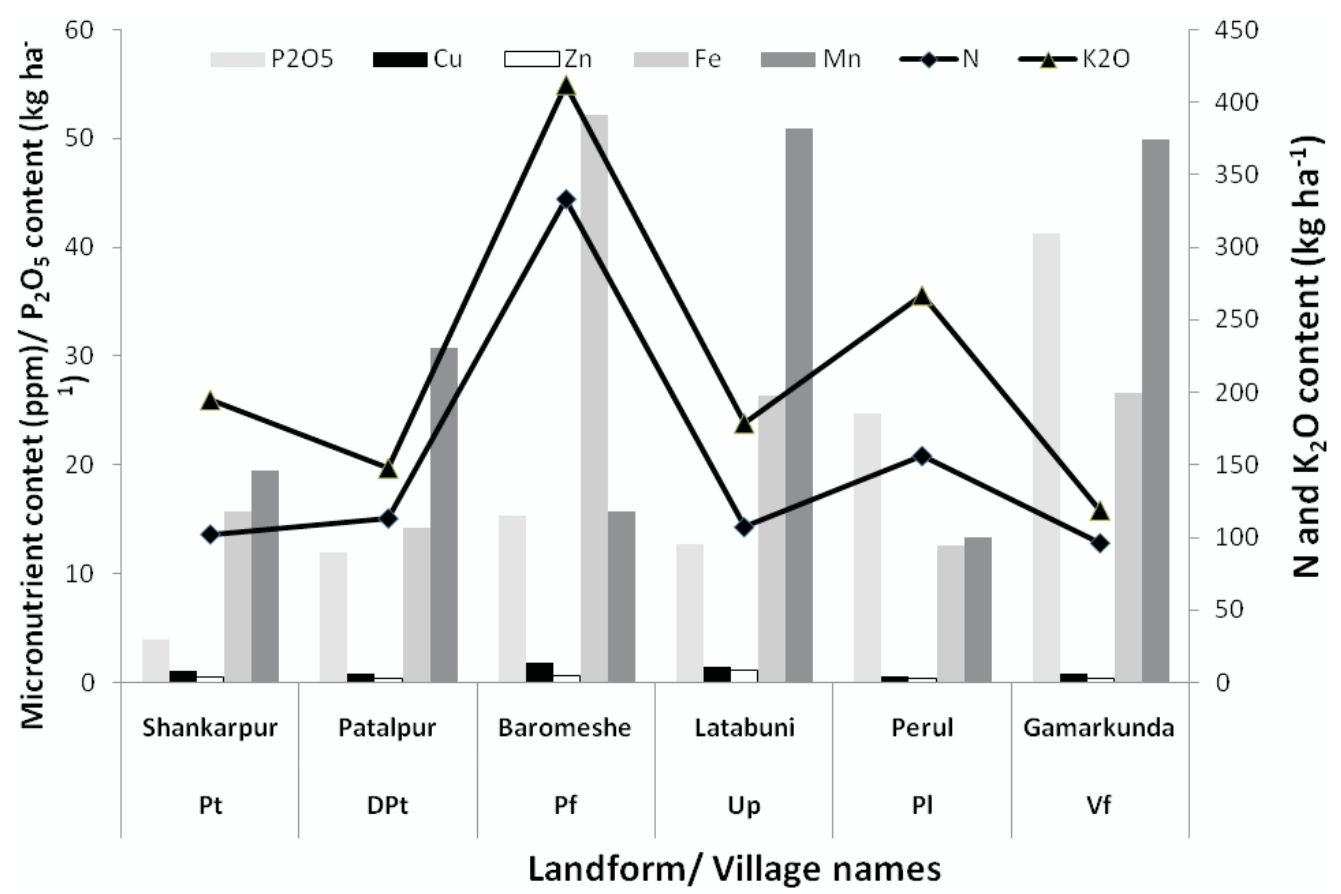

Fig. 3 Macro and micro nutrient distribution in surface soil

\section{Soil classification}

Based on the morphological and physico-chemical characterization of soils, the rice growing soils under different landforms of Rajnagar block has been classified upto family level (Soil Survey Staff, 2010). Soils were classified as Fine loamy Typic Haplustalfs, Fine loamy Aeric Endoaqualfs, Fine loamy Typic Haplustalfs, Fine loamy Typic Haplustepts, Fine loamy Aeric Epiaquepts and Fine loamy Oxyaquic Haplustalfs under plateau top, dissected plateau, plateau fringe, undulating upland, alluvial plains and valley fill landform situations, respectively. Soils under plateau fringe and valley fill areas have a rate of clay illuviation of more than 1.2 times with increasing depth and qualified as Alfisols. Subsequently, Chroma of 2 for soils under dissected plateau and plains indicates the presence of moisture and gleying in the lower soil horizons. All rice soils belong to fine loamy family with $18-35 \%$ clay content in the control section.

\section{Soil organic carbon stock in different landforms under rice cultivation}

Soil organic carbon stock has been evaluated under rice based system situated in different landforms. The double crop rice ecology (rice-mustard) showed significantly $(\mathrm{P}=0.05)$ higher soil organic carbon stock $\left(14.5 \mathrm{Mg} \mathrm{ha}^{-1}\right)$ in surface as compared to the other monocrop rice ecologies 
(on average $8.1 \mathrm{Mg} \mathrm{ha}^{-1}$ ). Moreover, valley fill soils had the highest surface SOC stock (14.5 $\mathrm{Mg} \mathrm{ha}^{-1}$ ) followed by plains (10.4 $\left.\mathrm{Mg} \mathrm{ha}^{-1}\right)$, plateau fringe (7.7 $\left.\mathrm{Mg} \mathrm{ha}^{-1}\right)$, plateau top (8.1 $\mathrm{Mg} \mathrm{ha}^{-1}$ ), dissected plateau (7.2 $\mathrm{Mg} \mathrm{ha}^{-1}$ ) and upland (6.9 Mg $\left.\mathrm{ha}^{-1}\right)$. Among the monocropped rice growing systems soils of plains had significantly $(\mathrm{P}=0.05)$ higher surface $\mathrm{SOC}$ stock followed by plateau top and plateau fringe. The highest SOC in the valley fill region might be the result of organic carbon input into the soil by residues left by the second crop in addition to rice. Moreover, the higher yield derived crop residues in plains and valley fill regions might be the reason for higher SOC stock in these regions (Mandal et al., 2007). On the other hand, because of the less surface erosion (slope $0-1 \%$ ) in plateau top and the greater accumulation of plateau and hillock wash in the depositional phase of plateau fringe might increase the SOC stock of the respective areas as compared to the other landforms. The lower SOC stock indicates the unsaturated condition of the soil for SOC appetite, which may lead the future planner to decide the new crop planning under changing climatic conditions with best carbon management practices for soil health security (Mandal, 2011). Severe erosion might cause the lower SOC stock in dissected plateau and upland soils. The SOC stock of the selected soil profiles showed similar result to surface SOC stock (Table 3). The total profile SOC stock was significantly $(\mathrm{P}=0.05)$ higher in valley fill $\left(45.2 \mathrm{Mg} \mathrm{ha}^{-1}\right)$ as compared to the soils of plains (31.3 $\left.\mathrm{Mg} \mathrm{ha}^{-1}\right)$, plateau fringe (28.5 $\left.\mathrm{Mg} \mathrm{ha}^{-1}\right)$, plateau top (24.2 $\left.\mathrm{Mg} \mathrm{ha}^{-1}\right)$, dissected plateau (23.0 $\mathrm{Mg} \mathrm{ha}^{-1}$ ) and undulating upland (19.9 $\mathrm{Mg} \mathrm{ha}^{-1}$ ) depicting the presence of better soil health in valley fill, plains and plateau fringe areas as compared to the other landforms (Fig 4).

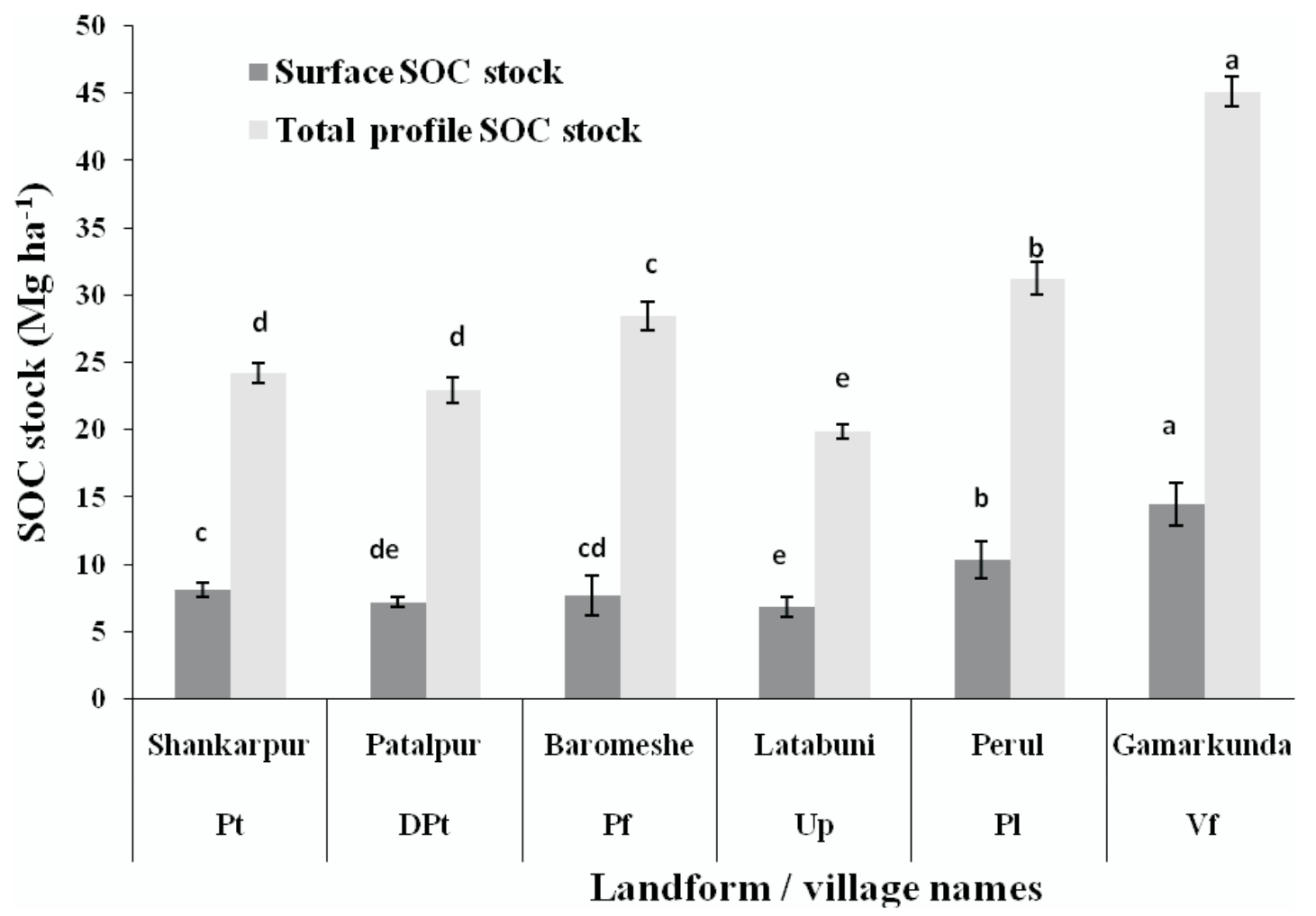

Fig. 4 Soil organic carbon stock in rice soils

\section{Conclusion}

The present study corroborates that the rice growing soils of Rajnagar block of Birbhum district, West Bengal are primarily fine loamy Alfisols and Inceptisols. The soils were classified as Typic Haplustepts, Aeric Endoaqualfs, Aeric
Epiaquepts, Typic Haplustalfs, Oxyaquic Haplustalfs with varying range of characteristics. Soils are mainly acidic to neutral in nature with low organic carbon and CEC. The surface and total profile soil organic carbon stock ranged from 7.2 to $14.5 \mathrm{Mg} \mathrm{ha}^{-1}$ and from 19.9 to $45.2 \mathrm{Mg} \mathrm{ha}^{-1}$, 
respectively, depicting the higher potential towards carbon capturing capacity, which lies in the centre of attraction for the present day research under climate change scenario.

\section{Reference}

Bhattacharyya T., Sarkar D. and Pal D.K. (Eds.) (2009). Soil Survey Manual. NBSS \& LUP Publication No. 146, India. $400 \mathrm{pp}$.

Bray R. and Kurtz T. (1945). Determination of total organic and available forms of phosphorus. Soil Science Society of America Journal 59, 39-45.

Christensen L.M. and Fulmer E.I. (1927). A modified Kjeldahl method for the determination of the nitrogen content of yeast. Plant Physiology. 2, 455-460.

District Statistical Handbook. (2012). Birbhum district, West Bengal. Chapter 18.1.

Gangopadhyay S.K., Sarkar D., Sahoo A.K. and Singh S.K. (2012). Soils of the rainfed regions of West Bengal and their productivity potential appraisal. Journal of the Indian Society of Soil Science, 60 (2), 83-91.

Gangopadhyay S.K., Obi Reddy, G.P., Mukhopadhyay, S. and Singh S.K. (2015). Characterization of landforms and soils in complex toposequence of Subarnarekha catchment, Chhotanagpur plateau using remote sensing and GIS.Agropedology, 25 (1), 95-109.

Gathala M.K., Kumar V., Sharma P.C., Saharawat Y.S., Jat H.S., Singh M., Kumar A., Jat M.L., Humphreys E., Sharma D.K., Sharma S. and Ladha J.K. (2013). Optimizing intensive cereal-based cropping systems addressing current and future drivers of agricultural change in the northwestern IndoGangetic Plains of India. Agriculture, Ecosystem and Environment 177, 85-97.

Gupta Choudhury S., Srivastava S., Singh R., Chaudhari S.K., Sharma D.K., Singh S.K. and Sarkar D. (2014). Tillage and residue management effects on soil aggregation, organic carbon dynamics and yield attribute in rice-wheat cropping system under reclaimed sodic soil. Soil and Tillage Research 136, 76-83.

Hanway J.J. and Heidel H. (1952). Soil analysis methods as used in Iowa State College Soil Testing Laboratory. Iowa Agriculture 57, 1-31.

Hossain M.S., Hossain A., Sarkar M.A.R., Jahiruddin M., Silva J.A.T.D. and Hossain M.I. (2016).
Productivity and soil fertility of the rice-wheat system in the High Ganges River Floodplain of Bangladesh is influenced by the inclusion of legumes and manure. Agriculture, Ecosystems and Environment 218, 40-52.

Jackson M.L. (1973). Soil Chemical Analysis. Prentice Hall India Pvt. Ltd., New Delhi, pp. 498.

Keating B.A., Carberry P.S., Bindraban P.S., Asseng S., Meinke H. and Dixon J. (2010). Eco-efficient agriculture: Concepts, challenges and opportunities. Crop Science 50 (Suppl. 1), 109-119.

Ladha J.K., Pathak H., Padre A.T., Dave D., Gupta R.K., et al. (2003). Productivity trends in intensive rice-wheat cropping systems in Asia. In: Ladha, J.K. (Ed.), Improving the Productivity and Sustainability of Rice-Wheat Systems: Issues and Impacts. ASA Special Publication 65, Madison, WI, pp. 45-76ASA, CSSA, and SSA.

Mandal B. (2011). Soil organic carbon research in India-A way forward. Journal of the Indian Society of Soil Science, 59 (Suppl.), S9-S22.

Mandal B., Majumder B., Adhya T.K., Bandyopadhyay P.K., Gangopadhyay A., Sarkar D., Kundu M.C., Gupta Choudhury S., Hazra G.C., Kundu S., Samantaray R.N. and Mishra A.K. (2008). Potential of doublecropped rice ecology to conserve organic carbon under subtropical climate. Global Change Biology 14, 2139-2151.

Mandal B., Majumder B., Bandyopadhyay P.K., Hazra G.C., Gangopadhyay A., Samantaray R.N., Mishra A.K., Chaudhury J., Saha M.N. and Kundu S. (2007). The potential of cropping systems and soil amendments for carbon sequestration in soils under long-term experiments in subtropical India. Global Change Biology 13, 357-369.

Soil Survey Staff (1993). Soil Survey Manual, Agriculture Handbook No. 18, USDA, Washington, DC, USA.

Soil Survey Staff (2010). 'Keys to Soil Taxonomy'. Eleventh Edition. USDA. Natural Resource Conservation Service, Washington, D. C.

Teka K., Nyssen J., Teha N., Haile M. and Deckers J. (2015). Soil, land use and landform relationship in the Precambrian lowlands of northern Ethiopia. Catena. 84-91.

Tilman D., Baizer C., Hill J. and Befort B.L. (2011). Global food demand and the sustainable intensification of 
agriculture. Proc. Nat. Acad. Sci. U. S. A. 108, 20260-20264.

Velayutham M., Mandal D. K., Mandal C. and Sehgal J. (1999). Agro-ecological sub-regions of India for planning and development. NBSS and LUP. Pub. No. 35, 372p.
Walkley A. and Black I.A. (1934). An examination of the Degtjareff method for determining soil rganic matter and a proposed modification of the chromic acid titration method. Soil Science 37, 29-38.

Received: August 2016 